Canadian

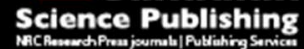

Canadian Journal of Chemistry Revue canadienne de chimie

\title{
Sintered Polymeric Binders for Li-ion Battery Alloy Anodes
}

\begin{tabular}{|r|l|}
\hline Journal: & Canadian Journal of Chemistry \\
\hline Manuscript ID & cjc-2017-0728.R1 \\
\hline Manuscript Type: & Article \\
\hline Date Submitted by the Author: & 25-Jan-2018 \\
\hline $\begin{array}{r}\text { Complete List of Authors: } \\
\begin{array}{r}\text { Is the invited manuscript for } \\
\text { consideration in a Special } \\
\text { Issue?: }\end{array}\end{array}$ & $\begin{array}{l}\text { Hatchard, Timothy; Dalhousie University, Chemistry } \\
\text { Obrovac, Mark; Dalhousie University, Chemistry }\end{array}$ \\
\hline Keyword: & $\begin{array}{l}\text { lithium-ion batteries, alloy negative electrodes, silicon alloys, electrode } \\
\text { binders }\end{array}$ \\
\hline &
\end{tabular}

SCHOLARONE $^{\text {IM }}$

Manuscripts 
$4 \quad{ }^{1}$ Department of Chemistry, Dalhousie University, Halifax, N.S., B3H 4R2 Canada

$5 \quad{ }^{2}$ Department of Physics and Atmospheric Science, Dalhousie University, Halifax, N.S.,

$9 *$ - corresponding author: mnobrovac@dal.ca 


\section{Abstract}

2 The cycling performance in $\mathrm{Li}$ half cells of $\mathrm{Si}$ alloy electrodes with 3 polyvinylidene fluoride or polyimide binders were evaluated after the electrodes were

4 cured at temperatures below and above the binder carbonization temperature. After

5 carbonization, the cycling performance of electrodes using polyvinylidene fluoride binder

6 improved considerably, but still suffered from capacity fade. Electrodes with carbonized

7 polyimide binder had superior performance and showed no capacity fade after 100

8 cycles. The superior performance of carbonized polyimide electrodes is thought to be

9 related to polyimide's high carbon yield upon heating, resulting in the formation of a 10 uniform carbon coating on alloy surfaces. These results suggest that new high 11 performance binders for alloy electrodes might be derived by the carbonization of 12 polymers with a high carbon yield that lead to the formation of uniform carbon coatings 13 on alloy particles. 


\section{1. Introduction}

A promising avenue to achieve the goals of lower cost and higher energy density

4 in Li-ion cells is the use of alloy anodes based on abundant materials, such as $\mathrm{Si}$ or Sn.

$5 \mathrm{Si}$ and $\mathrm{Sn}$ alloys can result in high energy density gains when implemented in Li-ion

6 cells. $^{1}$ The drawback of these materials, is their large volume expansion upon lithiation,

7 which is $280 \%$ for pure $\mathrm{Si}^{1-3}$ This volume expansion causes cracking and pulverization

8 of the electrode, and disruption of the solid electrolyte interphase (SEI), which leads to

9 capacity loss and failure of the cell. It also can result in mechanical failure of the

10 electrode, requiring the use of special polymer binders. ${ }^{1}$

11 It has been found that binders that perform well in alloy coatings have certain

12 specific properties. These are: good adhesion to both the alloy particles and current

13 collector, complete surface coverage of the alloy particles to reduce electrolyte

14 decomposition, and the ability to tolerate volume expansion by stretching or self-healing

15 to maintain the structural integrity of composite coatings. ${ }^{1,4-11}$ It has been suggested that

16 good surface coverage of the binder is required to form an "artificial SEI layer", which

17 minimizes further SEI formation, thus reducing irreversible capacity. ${ }^{8}$ It has also been

18 shown that electrically conducting polymer binders that fully encapsulate the alloy

19 particles not only provide the benefits described, but also form a conductive matrix that

20 leads to improved cycling by maintaining particle electrical contact. ${ }^{12,13}$ Recently, we

21 have suggested that electroactive binders such as polyimide or phenolic resin undergo full

22 reduction to hydrogen containing carbons when lithiated to $0 \mathrm{~V} \cdot{ }^{9,10}$ The resulting

23 electrode, now an alloy/carbon composite with no polymer binder, has excellent cycling 
1 performance. Apparently the hydrogen containing carbon serves as a conductive binder

2 and, in addition, provides additional capacity to the electrode. This effect has been

3 recently confirmed by Yoon et al. ${ }^{14}$ We suspect that most conductive binders that have

4 been proposed are reduced during lithiation and work in a similar manner.

5 Since binders that undergo electrochemical reduction to carbon perform well, this

6 naturally begs the question as to whether a thermally carbonized binder would perform

7 equally well. Carbonized binders have been used for structural materials, for instance in

8 carbon-carbon composites. Hassan et al. have reported the use of sintered PVDF as an

9 effective binder for a Si nanoparticle electrode. ${ }^{15}$ In this study, the use of carbonized

10 polymers as high performance binders in alloy electrodes will be explored using

11 carbonized aliphatic PVDF and aromatic polyimide (PI) binders.

\section{2. Experimental}

142.1 Electrode preparation.

15 Electrode coatings were made by mixing 3M L-20772 V6 Si alloy, hereafter

16 called V6, (3 $\mu \mathrm{m}$, from 3M Co., St. Paul, MN) and graphite (SFG6L Timcal), binder and

17 carbon black (C-NERGY Super C 65, Timcal) in N-methyl-2-pyrrolidone (NMP, Sigma

18 Aldrich, anhydrous 99.5\%) in a 60/28/2/10 V6/SFG6L/SuperC/binder weight ratio.

19 Binders used were polyvinylidene fluoride resin (PVDF, HSV $900 \mathrm{Kynar}{ }^{\circledR}$,), and

20 aromatic polyimide (PI, purchased as a $20 \%$ solution of polyamic acid in NMP, HD

21 MicroSystems). One PVDF electrode was formulated to have double the amount of

22 binder, resulting in a 60/28/2/20 V6/SFG6L/SuperC/binder weight ratio. Electrode

23 slurries were mixed for one hour in a Retsch PM200 planetary mill at $100 \mathrm{rpm}$ with four 
$11 / 2$ " tungsten carbide balls and then spread onto copper or nickel foil with a 0.004 " doctor

2 blade. Coatings were dried in air at $120^{\circ} \mathrm{C}$ for one hour. After drying in air, circular disks

3 with an area of $1.9 \mathrm{~cm}^{2}$ were punched from the electrode coatings to be used as cathodes

4 in Li half cells. These disks were then heated to $600{ }^{\circ} \mathrm{C}$ at a rate of $10{ }^{\circ} \mathrm{C} /$ minute in

5 flowing Ar and held for 3 hours. Exhaust gas from the tube furnace was flowed through

6 an oil bubbler and then through a water bubbler containing calcium carbonate chips in

7 order to neutralize any HF produced during the annealing of films containing PVDF.

8 After cooling, the disks were transferred to an Ar filled glove box without air exposure.

9 Alloy containing electrodes are designated here with the notation

10 alloy/graphite/[binder](heating temperature), for example: alloy/graphite/PVDF $\left(600^{\circ} \mathrm{C}\right)$.

11 The specific capacities of these alloy containing electrodes are reported here in terms of 12 the total electrode coating mass.

13 Binder only electrodes were made by spreading $20 \%$ (wt) slurries of PVDF or PI

14 in NMP on $\mathrm{Cu}$ foil with a 0.004 " doctor blade. Coatings were dried in air at $120^{\circ} \mathrm{C}$ for

15 one hour. After drying in air, circular disks with an area of $1.9 \mathrm{~cm}^{2}$ were punched from

16 the electrode coatings to be used as cathodes in Li half cells. Some of these disks were

17 then heated to $300{ }^{\circ} \mathrm{C}$ or $600{ }^{\circ} \mathrm{C}$ at a rate of $10{ }^{\circ} \mathrm{C} /$ minute in flowing $\mathrm{Ar}$ and held for 3

18 hours. Tube furnace exhaust was treated as described above. TiN/PI electrodes were

19 prepared with an 83/17 v/v ratio by the same method as described in Reference. ${ }^{9}$ The

20 specific capacities of such electrodes are reported here in terms of the mass of binder as

21 measured after heating at $120^{\circ} \mathrm{C}$.

$22 \quad 2.2$ Electrode Structural Analysis 
1 X-ray diffraction (XRD) patterns of unheated and heated binder powders were

2 collected with a Rigaku Ultima IV diffractometer equipped with a diffracted beam

3 graphite monochromator, scintillation detector, and a $\mathrm{Cu} \mathrm{K}$-alpha radiation source.

4 Polyamic acid powder was obtained by heating a $20 \%$ solution of polyamic acid in NMP

5 (HD Microsystems) in air at $120^{\circ} \mathrm{C}$ overnight and grinding the resulting solid residue.

6 The resulting powder was heated in flowing argon for 3 hours at $300{ }^{\circ} \mathrm{C}$ or $600{ }^{\circ} \mathrm{C}$.

7 Heated PVDF powder was obtained by heating PVDF as received under flowing argon

8 for 3 hours at $600{ }^{\circ} \mathrm{C}$. Scanning electron microscopy (SEM) was performed using a

9 Hitachi S-4700 Field Emission SEM.

102.3 Coin cell preparation.

11 The disks that were previously cut from the electrode coatings and heated under

$12 \mathrm{Ar}$, as described above, were used as working electrodes in Li half cells. Typical active

13 material loadings were about $1.8-2.0 \mathrm{mAh} / \mathrm{cm}^{2}$ for V6/graphite electrodes. Coin cells

14 were assembled in an argon-filled glove box. Lithium metal foil was used as the counter

15 electrode. Two layers of Celgard 2301 were used as separators. $1 \mathrm{M} \mathrm{LiPF}_{6}$ in a solution of

16 ethylene carbonate, diethyl carbonate and monofluoroethylene carbonate $(1 \mathrm{M} \mathrm{LiPF} 6$ in

17 EC/DEC/FEC; 3:6:1 by volume, BASF) were used as the electrolyte. Coin cells were

18 cycled using a Maccor Series 4000 Automated Cycler. V6/graphite electrodes were

19 cycled with potential limits of $0.005-1.5 \mathrm{~V}$ for the first cycle with a rate of $\mathrm{C} / 10$ and a

$20 \mathrm{C} / 40$ trickle discharge at $0.005 \mathrm{~V}$. Subsequent cycling was performed between $0.005-$

$210.900 \mathrm{~V}$ at a rate of $\mathrm{C} / 4$ with a $\mathrm{C} / 20$ trickle discharge at $0.005 \mathrm{~V}$. Binder only and

22 binder/TiN electrodes were cycled between limits of $0.005-2.0 \mathrm{~V}$ at a rate of $\mathrm{C} / 25$ with

23 a C/50 trickle discharge at $0.005 \mathrm{~V}$. 
2.4 Thermogravimetric analysis.

2 Thermogravimetric analysis (TGA) was performed using a TG 209 F3 (Netzsch)

3 in Ar. Samples of the dried binders were placed in $\mathrm{Al}_{2} \mathrm{O}_{3}$ cups and then loaded into the

4 heating chamber. The chamber was purged with Ar to remove any air before heating.

5 Heating rate was $5{ }^{\circ} \mathrm{C} / \mathrm{min}$ to a maximum temperature of $600{ }^{\circ} \mathrm{C}$.

\section{Results}

9 Figure 1 shows the TGA curves of polyamic acid and PVDF. PVDF is stable at 10 temperatures up to about $420{ }^{\circ} \mathrm{C}$. Above $400{ }^{\circ} \mathrm{C}$ PVDF decomposes, resulting in a rapid 11 mass loss, with only about $20 \%$ of the initial mass remaining at $600{ }^{\circ} \mathrm{C}$. This behavior is

12 typical of aliphatic polymers, and results in the formation of hydrogen containing carbons 13 as a residue, ${ }^{16}$ as confirmed by XRD below. The TGA curve for polyamic acid shows 14 that it undergoes an initial rapid mass loss, at about $150{ }^{\circ} \mathrm{C}-300{ }^{\circ} \mathrm{C}$, which is the 15 nominal temperature at which polyamic acid imidizes to form PI. This weight loss can be

16 attributed to the evaporation of water, which is a product of the imidization reaction. The

17 PI formed is then stable to just over $500{ }^{\circ} \mathrm{C}$. Above this temperature a second rapid mass

18 loss begins that is ongoing at the $600{ }^{\circ} \mathrm{C}$ end point of the experiment, corresponding to 19 the thermal carbonization of PI.

20 Figure 2(a-d) show XRD patterns of PVDF and PI binders heated at the same 21 temperatures used to make the electrode coatings in this study. The XRD pattern of

22 PVDF at $120^{\circ} \mathrm{C}$ (Figure 2(a)) is indicative of crystalline ordering of the polymer. After

23 heating to $600^{\circ} \mathrm{C}$ (Figure 2(b)) the XRD pattern is consistent with a hard carbon with 
1 single layer stacking, as has been observed previously. ${ }^{16}$ The XRD pattern of PI at $300^{\circ} \mathrm{C}$

2 (Figure 2(c)) is typical of a disordered polymer with some short range ordering. After

3 heating to $600^{\circ} \mathrm{C}$, the XRD pattern (Figure 2(d)) is also typical of a hard carbon with

4 single layer stacking. ${ }^{16}$

5 In order to directly measure the electrochemistry of cured and sintered PI and

6 PVDF in a composite electrode, electrode coatings were made with these binders and

7 inactive TiN powder, which was used as an inactive conductive filler to take the place of

8 active material. As described in Reference 9, this allows binders to be studied in the

9 same environment as they exist in composite electrode coatings without electrochemical

10 interference from active materials. Figure 2 shows the potential vs. capacity curve of PI

11 and PVDF binders in these electrodes. All capacities are calculated with respect to the

12 mass of the binder initially used to prepare the electrodes and are not corrected for the

13 weight loss that occurs during heating. This was done to compare irreversible capacities

14 in a meaningful way. In addition, cell makers would typically measure capacities as a

15 function of the amount of materials added during electrode preparation.

16 Figure $3(\mathrm{a}-\mathrm{c})$ shows the potential vs. capacity curves of TiN/PVDF electrodes

17 after heating to $120{ }^{\circ} \mathrm{C}, 300{ }^{\circ} \mathrm{C}$, and $600{ }^{\circ} \mathrm{C}$, respectively. PVDF is essentially

18 electrochemically inactive at $120^{\circ} \mathrm{C}$ and $300{ }^{\circ} \mathrm{C}$. However the irreversible capacity at

$19300{ }^{\circ} \mathrm{C}$ is increased. At $600{ }^{\circ} \mathrm{C}$ the TiN/PVDF electrode has considerable irreversible

20 and reversible capacity. We suspect that the increase in irreversible capacity with

21 increasing temperature is related to the formation of $\mathrm{Cu}_{2} \mathrm{O}$ on the surface of the current

22 collector foil, despite efforts of maintaining an inert atmosphere. Indeed, the first

23 lithiation potential vs. capacity curve is very similar to that reported for $\mathrm{Cu}_{2} \mathrm{O}$ by 
1 Grugeon et al., in which $\mathrm{Cu}_{2} \mathrm{O}$ is first reduced in a plateau extending from about $1.2 \mathrm{~V}$ -

$2 \quad 1.5 \mathrm{~V}$ followed by a lower potential plateau at about $0.8 \mathrm{~V}$ which was ascribed to capacity

3 from SEI formation. ${ }^{17}$ To provide further evidence that this increase in capacity is related

4 to the current collector, the $\mathrm{Cu}$ foil current collector of the TiN/PVDF electrode was

5 replaced by $\mathrm{Ni}$ foil (also shown in Figure 3(c)) which is less susceptible to oxidation.

6 This results in the disappearance of the high potential plateau and the irreversible

7 capacity is much reduced. Therefore, we ascribe much of the first discharge capacity of

8 the PVDF electrode that was heated at $600{ }^{\circ} \mathrm{C}$ to the oxidation of the $\mathrm{Cu}$ current collector.

9 The increased capacity shown in the Ni current collector is likely related to the residual

10 carbon from the decomposition of PVDF.

11 Figure $3(\mathrm{~d}, \mathrm{e})$ show potential vs. capacity curves of TiN/PI electrodes that were

12 heated at $300{ }^{\circ} \mathrm{C}$ and $600{ }^{\circ} \mathrm{C}$, respectively. The potential vs. capacity curve of PI cured at

$13 \quad 300{ }^{\circ} \mathrm{C}$ has large irreversible capacity, large reversible capacity, and large hysteresis; all

14 of which are typical of hydrogen containing carbons. ${ }^{18}$ We have suggested that PI

15 carbonizes during lithiation previously ${ }^{9}$ and this mechanism has been verified by Yoon et

16 al. $^{14}$ After heating to $600^{\circ} \mathrm{C}$ the reversible capacity and polarization becomes reduced

17 and the potential vs. capacity curve is similar to that of heated PVDF, shown in Figure

18 3(c). This is consistent with hydrogen loss, which occurs when hydrogen containing

19 carbons are heated. ${ }^{18}$ The plateaus during the first discharge of the TiN/PI electrodes that

20 were heated to $600{ }^{\circ} \mathrm{C}$ also resemble those of the TiN/PVDF electrode heated to the same

21 temperature, which we attributed to the formation of $\mathrm{Cu}_{2} \mathrm{O}$. Also shown in Figure 3(e) is

22 a potential vs. capacity curve of the TiN/PI electrode coated on a Ni current collector and

23 heated to $600{ }^{\circ} \mathrm{C}$. The high potential plateau related to $\mathrm{Cu}_{2} \mathrm{O}$ reduction disappears when 
1 a Ni current collector is used, but the first cycle capacity below $1 \mathrm{~V}$ remains high. This

2 may be due to higher hydrogen content in this aromatic carbon than PVDF heated to the

3 same temperature.

4 Figure $4(\mathrm{a}-\mathrm{d})$ show SEM images of alloy/graphite/PVDF $\left(120^{\circ} \mathrm{C}\right)$,

5 alloy/graphite/PVDF $\left(600^{\circ} \mathrm{C}\right)$, alloy/graphite $/ \mathrm{PI}\left(300^{\circ} \mathrm{C}\right)$, and alloy/graphite $/ \mathrm{PI}\left(600^{\circ} \mathrm{C}\right)$

6 electrodes, respectively. The PVDF binder is clearly visible in the

7 alloy/graphite/PVDF $\left(120^{\circ} \mathrm{C}\right)$ electrode (Figure $\left.4(\mathrm{a})\right)$ as filaments bridging particles. At

$8600^{\circ} \mathrm{C}$ (Figure 4(b)), the PVDF is no longer visible. All alloy and graphite surfaces

9 appear smooth and pristine. This is consistent with the TGA results, showing that nearly

10 all of the PVDF decomposes to form gaseous components at this temperature. In

11 contrast, alloy particles in the alloy/graphite/PI $\left(300^{\circ} \mathrm{C}\right)$ electrode (Figure $\left.4(\mathrm{c})\right)$ are all

12 covered with a rough/granular layer of PI polymer. Despite the surface roughness, all

13 alloy particles were found to be completely coated with this PI layer, while the graphite

14 particles appear pristine. PI binder's ability to form a uniform coating on the alloy

15 particles is likely due to the strong ester-like bonds formed between PI and Si alloys. ${ }^{9}$

16 These are due to the reaction of carboxylic acid groups of poly(amic acid) with silanol

17 groups $(\mathrm{Si}-\mathrm{OH})$ on the surface of silicon alloys. At $600^{\circ} \mathrm{C}$ (Figure $4(\mathrm{~d})$ ) there is little

18 change. All graphite particle surfaces appear pristine, while a rough, but uniform coating

19 on the alloy particles is still visible.

20 The SEM and XRD results show that alloy/graphite/PVDF $\left(600^{\circ} \mathrm{C}\right)$ coating is

21 likely a composite of the active particles with a small amount of carbon residue. This is

22 consistent with the findings of Hassan et al. ${ }^{15}$ However, no particles could be found that

23 showed any sign of carbon coating. This is likely because of the small amount of carbon 
1 residue in the alloy/graphite/PVDF $\left(600^{\circ} \mathrm{C}\right)$ due to PVDF's large mass loss during heating,

2 as indicated by TGA. In contrast, the alloy/graphite $/ \mathrm{PI}\left(600^{\circ} \mathrm{C}\right)$ coating comprises

3 composite of active particles with a much greater carbon content. The amount of carbon

4 is sufficient to uniformly coat all of the alloy particles in the coating, as observed by

5 SEM.

6 Figure 5(a) shows the potential versus capacity plot of an

7 alloy/graphite/PVDF $\left(120^{\circ} \mathrm{C}\right)$ electrode. We have reported good cycling for the same

8 electrode formulation using PI, Phenolic Resin and LiPAA binders in previous

9 studies. ${ }^{9,10,19}$ The first discharge of the alloy/graphite/ $\operatorname{PVDF}\left(120^{\circ} \mathrm{C}\right)$ electrode is

10 comparable to that shown in Reference 19 using LiPAA binder. However, the

11 irreversible capacity is significantly higher, and even though only 2.5 cycles are shown,

12 there are clear signs of rapid capacity fade. Figure 5(b) shows the cycling performance of

13 this cell, and confirms that the cycle life is very poor, with little capacity remaining after

14 only ten cycles. This demonstrates the poor performance of alloy electrodes with PVDF

15 binder, which is well known. ${ }^{1}$ This poor performance is likely due to the observed

16 morphology of PVDF (Figure 4(a)), which forms filaments in the coating, rather than

17 forming a uniform coating on the particles. ${ }^{1}$

18 Figure 5(c) shows the potential versus capacity curve for an

19 alloy/graphite/PVDF $\left(600^{\circ} \mathrm{C}\right)$ electrode. The first cycle potential vs. capacity curve of this

20 cell is similar to that of the cell in Figure 3(a), however there is additional capacity at the

21 beginning of the first discharge above $0.2 \mathrm{~V}$. This is consistent with the additional

22 capacity observed when a TiN/PVDF electrode was heated to $600{ }^{\circ} \mathrm{C}$, as shown in Figure

232 2(c). Despite this additional initial capacity, the total first cycle discharge capacity of the 
1 alloy electrode heated at $600{ }^{\circ} \mathrm{C}$ is less than that of the electrode heated at $120{ }^{\circ} \mathrm{C}$. We

2 ascribe these effects to changes in the alloy structure, which results in capacity reduction

3 upon heating to $600^{\circ} \mathrm{C}$ due to grain growth. The cycling performance of the

4 alloy/graphite/PVDF $\left(600^{\circ} \mathrm{C}\right)$ electrode, shown in Figure 5(d) is much improved over the

5 alloy/graphite/PVDF $\left(120^{\circ} \mathrm{C}\right)$ electrode, shown in Figure 5(a). This is consistent with the

6 findings of Hassan et al., who attribute this effect to the formation of a conductive carbon

7 coating on the active particles. ${ }^{15}$ Here, no such coating was observed and the electrode

8 still has significant capacity fade, retaining only about $65 \%$ of its initial reversible

9 capacity after 100 cycles and poor coulombic efficiencies of less than $99.5 \%$.

10 Figure 6(a) shows the potential versus capacity curve for an

11 alloy/graphite/PI $\left(300^{\circ} \mathrm{C}\right)$ electrode. The first discharge potential vs. capacity curve of

12 this electrode also has significant capacity above $0.2 \mathrm{~V}$, which we ascribe to the reduction

13 of PI binder, as previously reported. ${ }^{9}$ This is also consistent with the large first cycle PI

14 reduction capacity shown in Figure 2(d). As we have reported previously, ${ }^{9}$ this electrode

15 has excellent cycle life, retaining about $95 \%$ of its initial capacity after 100 cycles and

16 good coulombic efficiencies that exceed $99.8 \%$ after cycle 40, as shown in Figure 4(b).

17 This good cycling performance was attributed to the formation of conductive carbon

18 produced by the reduction of PI during the first cycle. ${ }^{9}$ Figure 4(c) shows the potential

19 versus capacity curve of an alloy/graphite/ $\mathrm{PI}\left(600^{\circ} \mathrm{C}\right)$ electrode. Additional capacity

20 above $0.2 \mathrm{~V}$, compared to an alloy/graphite $/ \operatorname{PVDF}\left(120^{\circ} \mathrm{C}\right)$ electrode, is also present

21 during the first discharge, which is consistent with the significant first discharge capacity

22 of PI heated to $600{ }^{\circ} \mathrm{C}$ as shown in Figure 2(e). The alloy/graphite/PI $\left(600^{\circ} \mathrm{C}\right)$ electrode

23 has about $20 \mathrm{mAh} / \mathrm{g}$ less reversible capacity than the same electrode heated to $300{ }^{\circ} \mathrm{C}$ 
1 shown in Figure 4(a), again because of the lowered alloy capacity at $600{ }^{\circ} \mathrm{C}$, as discussed

2 above. Figure $4(\mathrm{~d})$ shows the cycling performance of the alloy/graphite $/ \mathrm{PI}\left(600^{\circ} \mathrm{C}\right)$

3 electrode. The cycling performance is excellent with almost no capacity loss in 100

4 cycles. This is a significant improvement in the cycling performance compared to the

5 same electrode cured at $300{ }^{\circ} \mathrm{C}$, which lost $5 \%$ capacity in the same number of cycles.

6 The difference in cycling performance of the alloy/graphite electrode using

7 PVDF binder heated to $600{ }^{\circ} \mathrm{C}$ in Ar shown in Figure 5(d) compared to the electrode

8 made under the same conditions except with PI binder, shown in Figure 6(d) is striking.

9 The alloy/graphite/ $\mathrm{PI}\left(600^{\circ} \mathrm{C}\right)$ performs much better than the alloy/graphite/ $\operatorname{PVDF}\left(600^{\circ} \mathrm{C}\right)$

10 electrode. One reason for this performance might be related to the difference in mass loss

11 that results when PVDF and PI are heated, as shown in Figure 1. During carbonization at

$12600{ }^{\circ} \mathrm{C}$, PVDF loses considerably more mass than PI. Therefore, very little residual

13 carbon remains when a PVDF electrode is heated to this temperature compared to a PI

14 electrode with the same formulation. As mentioned above, the additional carbon in the

15 heated PI electrode can uniformly coat the active particles. This may inhibit electrolyte

16 decomposition reactions and improve cycling.

17 To see if the lack of residual carbon is the cause of the poor performance of the

18 PVDF electrode, an alloy/graphite/ $\operatorname{PVDF}\left(600^{\circ} \mathrm{C}\right)$ electrode was prepared with double

19 PVDF content, to compensate for its additional weight loss during heating, compared to

20 PI. An SEM image of this coating is shown in Figure 7. Some of the alloy is now coated

21 with carbon in this electrode. Therefore the increased amount of PVDF has resulted in

22 some of the alloy surfaces becoming carbon coated after heating. However the coating is

23 not complete as in the case of PI and some of the alloy surfaces still appear pristine. The 
1 cycling performance of this electrode is shown in Figure 5(d). Increasing the PVDF

2 content does result in significant improvements in cycle life and coulombic efficiency.

3 However, the cycling performance of the alloy/graphite/PVDF $\left(600^{\circ} \mathrm{C}\right)$ electrode with

4 excess PVDF is still inferior to the alloy/graphite $/ \mathrm{PI}\left(600^{\circ} \mathrm{C}\right)$ electrode. This is likely due

5 to PI's ability to uniformly coat the active material particles, which leads to a uniform

6 carbon coating upon heating. Even when the PVDF content is doubled, an insufficient

7 amount of carbon residue is present to completely coat the alloy particles.

8 From these results we speculate that the improved cycling due to carbonizing

9 alloy electrodes is from the formation of a carbon coating on the alloy particles. The

10 cycling is optimized when the carbon coating uniformly coats the alloy particles, leaving

11 no bare alloy surfaces in contact with electrolyte. Based on these conclusions, carbon

12 precursors, such as PI, that have a high carbon yield upon heating are ideal for forming

13 carbonized alloy electrodes with good cycling performance, since they are more likely to

14 form a uniform carbon coating on the alloy particles, compared to low carbon yield

15 polymers, such as PVDF.

\section{4. Conclusion}

18 It was found that heat treating electrode coatings with PI or PVDF binders to 600

$19{ }^{\circ} \mathrm{C}$ in an inert atmosphere greatly improves their charge discharge cycling performance.

20 During this heat treatment these polymers decompose and carbonize. The cycle life of

21 cells made using electrodes with PVDF binder that were heated at $600{ }^{\circ} \mathrm{C}$ have greatly

22 superior cycle life compared to PVDF electrodes heated at temperatures below its

23 carbonization temperature. Even better cycling performance is obtained for $\mathrm{Si}$ alloy 
1 electrodes with PI binder that were heated to $600{ }^{\circ} \mathrm{C}$. The cycling performance of the Si

2 alloy electrodes with PI binder cells heated to $600{ }^{\circ} \mathrm{C}$ was also superior to Si alloy

3 electrodes with PI binder that were heated to $300^{\circ} \mathrm{C}$, and the irreversible capacity was

4 slightly reduced. The observation that binders work well after thermal carbonization is

5 further evidence that good binders, such as PI, become electrochemically reduced to form

6 hydrogen containing carbons.

7 It was speculated here that the superior performance of sintered PI binder 8 compared to sintered PVDF binder is due to PI's higher carbon yield during thermal

9 decomposition. As a result of this high carbon yield, a uniform carbon coating on the

10 alloy particles could be attained with PI binders after carbonizing the electrode. This

11 suggests that carbonizing aromatic carbons (soft carbon precursors) with high carbon

12 yield may result in binders for alloy electrodes with good cycling properties. We have

13 confirmed that this is true for sintered phenolic resin electrodes, which have a similar

14 carbon yield as PI and similar cycling performance. We plan to report on the relation of

15 carbon yield and cycling performance in a future publication.

\section{Acknowledgments}

18 The authors acknowledge funding from NSERC and 3M Canada under the

19 auspices of the Industrial Research Chair and Discovery grant programs. We also

20 acknowledge the support of the Canada Foundation for Innovation, the Atlantic

21 Innovation Fund and other partners that fund the Facilities for Materials Characterization

22 managed by the Institute for Research in Materials at Dalhousie University. 


\section{References}

3 (1) Obrovac, M. N.; Chevrier, V. L. Chem. Rev. 2014, 114, 11444.

4 (2) Obrovac, M. N.; Christensen, L. Electrochem. Solid-State Lett. 2004, 7 (5), A93.

5 (3) Obrovac, M. N.; Christensen, L.; Le, D. B.; Dahn, J. R. J. Electrochem. Soc. 2007, $6 \quad 154(9)$, A849.

7 (4) Li, J.; Christensen, L.; Obrovac, M. N.; Hewitt, K. C.; Dahn, J. R. J. Electrochem. Soc. 2008, 155 (3), A234.

9 (5) Hochgatterer, N. S.; Schweiger, M. R.; Koller, S.; Raimann, P. R.; Wöhrle, T.;

10 Wurm, C.; Winter, M. Electrochem. Solid-State Lett. 2008, 11 (5), A76.

11 (6) Bridel, J.-S.; Azaïs, T.; Morcrette, M.; Tarascon, J.-M.; Larcher, D. J.

12 Electrochem. Soc. 2011, 158 (6), A750.

13 (7) Komaba, S.; Yabuuchi, N.; Ozeki, T.; Han, Z.; Shimomura, K.; Yui, H.;

14 Katayama, Y.; Miura, T. J. Phys. Chem. B 2012, 116, 1380.

15 (8) Komaba, S.; Shimomura, K.; Yabuuchi, N.; Ozeki, T.; Yui, H.; Konno, K. J. Phys. $16 \quad$ Chem. C 2011, 115 (27), 13487.

17 (9) Wilkes, B. N.; Brown, Z. L.; Krause, L. J.; Triemert, M.; Obrovac, M. N. J. 18 Electrochem. Soc. 2016, 163 (3), A364.

19 (10) Hatchard, T. D.; Bissonnette, P.; Obrovac, M. N. J. Electrochem. Soc. 2016, 163

$20 \quad(9), 2035$.

21 (11) Wang, C.; Wu, H.; Chen, Z.; McDowell, M. T.; Cui, Y.; Bao, Z. Nat. Chem. 2013, $22 \quad 5(12), 1042$.

23 (12) Xun, S.; Song, X.; Battaglia, V.; Liu, G. J. Electrochem. Soc. 2013, 160 (6), A849. 
1 (13) Wu, H.; Yu, G.; Pan, L.; Liu, N.; McDowell, M. T.; Bao, Z.; Cui, Y. Nat.

$2 \quad$ Commun. 2013, 4, 1943.

3 (14) Yoon, T.; Chapman, N.; Nguyen, C. C.; Lucht, B. L. J. Mater. Sci. 2016.

4 (15) Hassan, F. M.; Chabot, V.; Elsayed, A. R.; Xiao, X.; Chen, Z. Nano Lett. 2014, 14 (1), 277.

6 (16) Zheng, T.; Liu, Y.; Fuller, E. W.; Tseng, S.; von Sacken, U.; Dahn, J. R. J. Electrochem. Soc. 1995, 142 (8), 2581.

8 (17) Grugeon, S.; Laruelle, S.; Herrera-Urbina, R.; Dupont, L.; Poizot, P.; Tarascon, J.M. J. Electrochem. Soc. 2001, 148 (4), A285.

10 (18) Zheng, T.; McKinnon, W. R.; Dahn, J. R. J. Electrochem. Soc. 1996, 143 (7), 112137.

12 (19) Du, Z.; Dunlap, R. A.; Obrovac, M. N. J. Electrochem. Soc. 2014, 161 (10), $13 \quad$ A1698.

\section{Figure Captions}

18 Figure 1 TGA curves of polyamic acid and PVDF collected at a heating rate of $5{ }^{\circ} \mathrm{C} / \mathrm{min}$ under Ar gas.

21 Figure 2 XRD patterns of pure binder polymers heated to temperatures as indicated. A 
4 Figure 3 Potential vs. capacity curves of PVDF and PI binders in TiN/binder coatings 5

and PI heated to $600^{\circ} \mathrm{C}$ in (b) and (d), so that the carbon 002 peak can be plotted more accurately. after heating to different temperatures, as indicated. Solid and dashed lines are for coatings on $\mathrm{Cu}$ and $\mathrm{Ni}$ current collectors, respectively.

Figure 4 SEM images of alloy/graphite/binder coatings cured at different temperatures: (a) alloy/graphite/ $\operatorname{PVDF}\left(120^{\circ} \mathrm{C}\right)$, (b) alloy/graphite/ $\operatorname{PVDF}\left(600^{\circ} \mathrm{C}\right)$, (b) alloy/graphite $/ \operatorname{PI}\left(300^{\circ} \mathrm{C}\right)$, and (c) alloy/graphite $/ \operatorname{PI}\left(600^{\circ} \mathrm{C}\right)$. Arrows in (c) and (d) indicate alloy surfaces coated with a rough layer of (c) PI or (d) carbonized (PI).

Figure 5 (a) Potential vs. capacity and (b) cycling performance of an alloy/graphite/PVDF $\left(120^{\circ} \mathrm{C}\right)$ electrode; (c) potential vs. capacity and (d) cycling performance of an alloy/graphite/PVDF $\left(600^{\circ} \mathrm{C}\right)$ electrode. These electrodes were all formulated to have $10 \mathrm{wt} . \%$ PVDF prior to heating. Also shown in blue in Figure 3(d) is the cycling performance of an alloy/graphite $/ \mathrm{PVDF}\left(600^{\circ} \mathrm{C}\right)$ electrode having $20 \mathrm{wt} . \%$ PVDF prior to heating.

Figure 6 (a) Potential vs. capacity and (b) cycling performance of an alloy/graphite/PI $\left(300^{\circ} \mathrm{C}\right)$ electrode; (c) potential vs. capacity and (d) cycling performance of an alloy/graphite/PI $\left(600^{\circ} \mathrm{C}\right)$ electrode. 
2 Figure $7 \mathrm{SEM}$ image of an an alloy/graphite/ $\operatorname{PVDF}\left(600^{\circ} \mathrm{C}\right)$ electrode having $20 \mathrm{wt} . \%$ PVDF prior to heating. The arrow in the figure indicates an alloy surface coated with a rough layer of carbonized PVDF. 
Figure 1

2

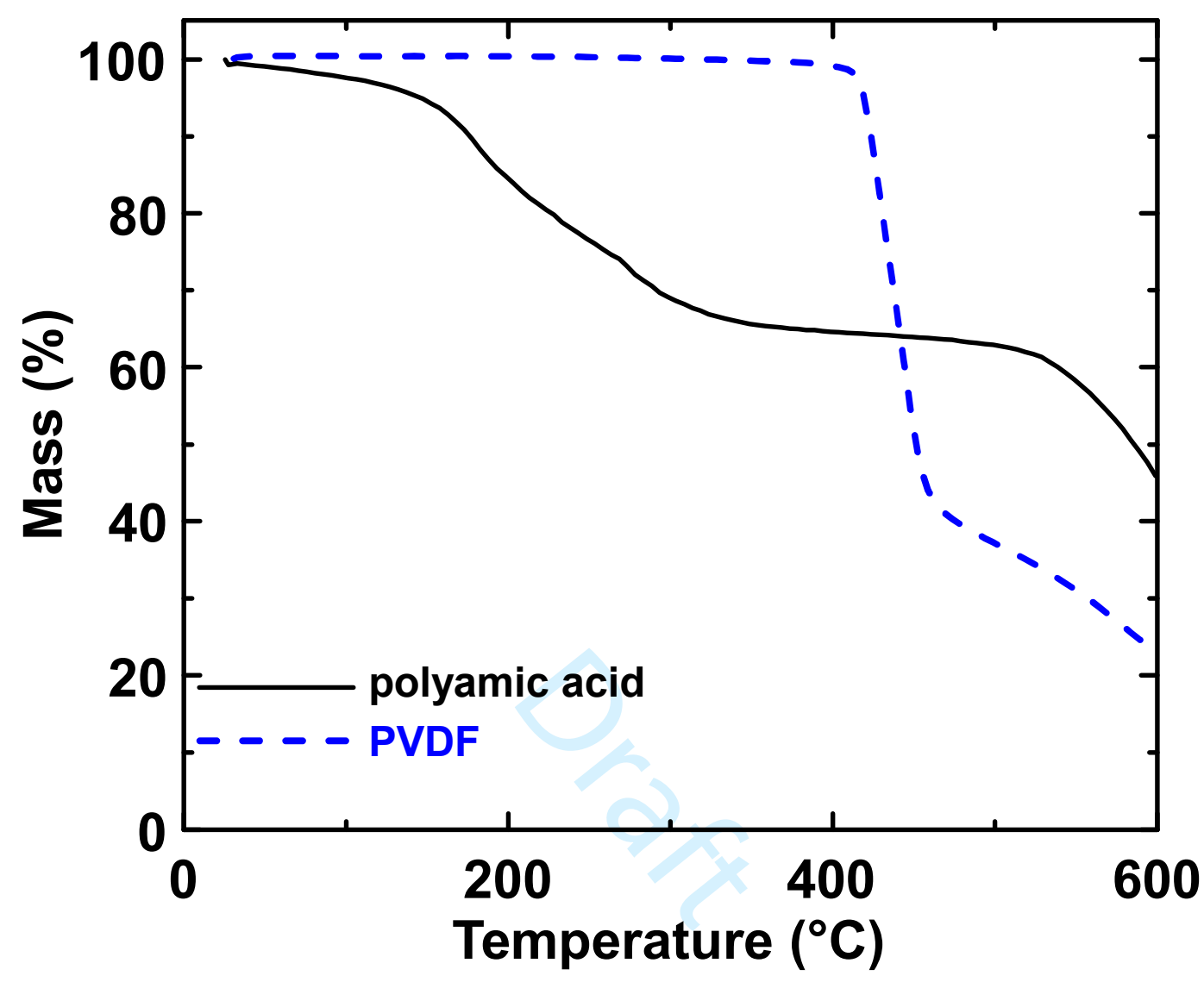

3 
Figure 2

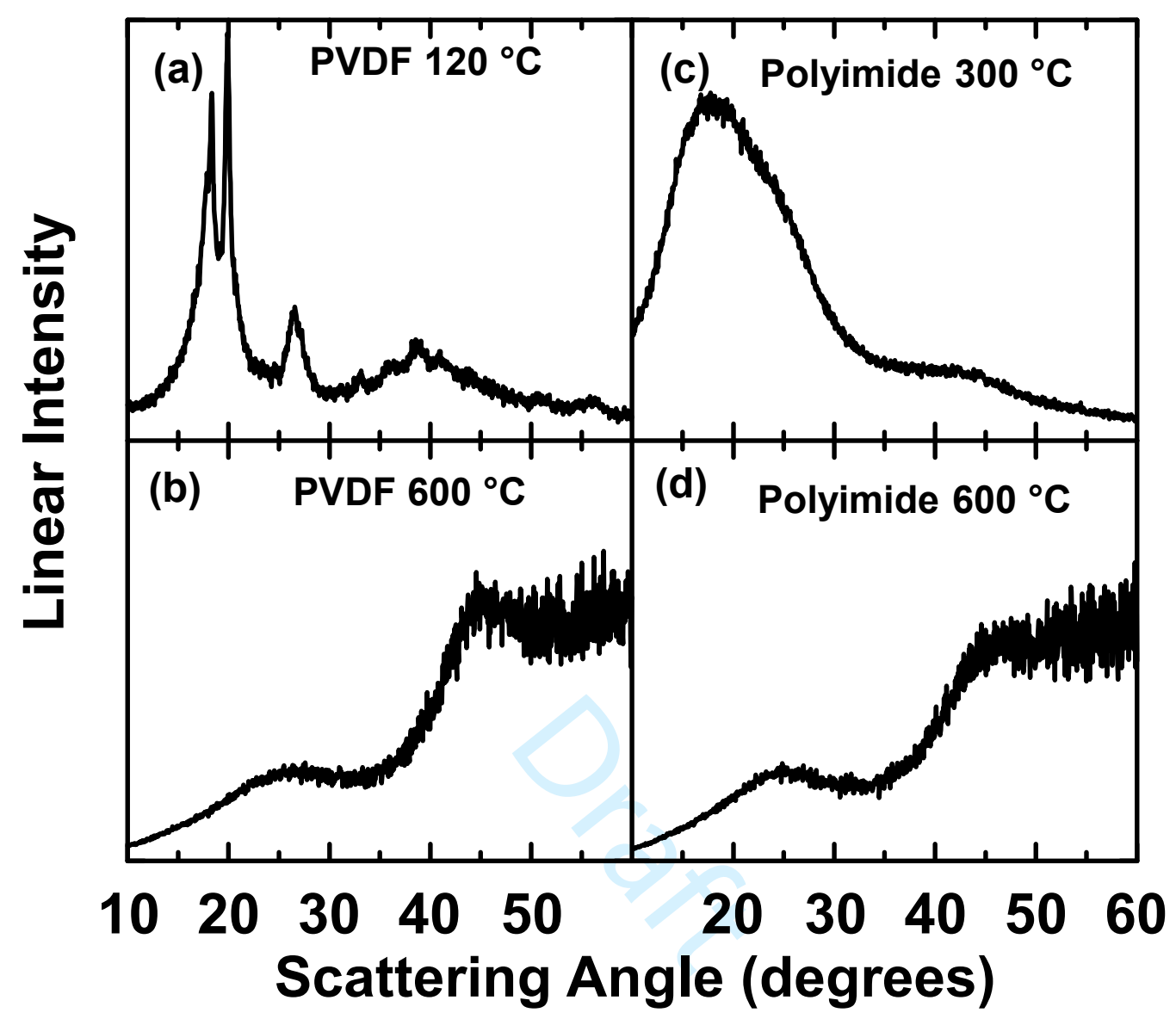

4
5 


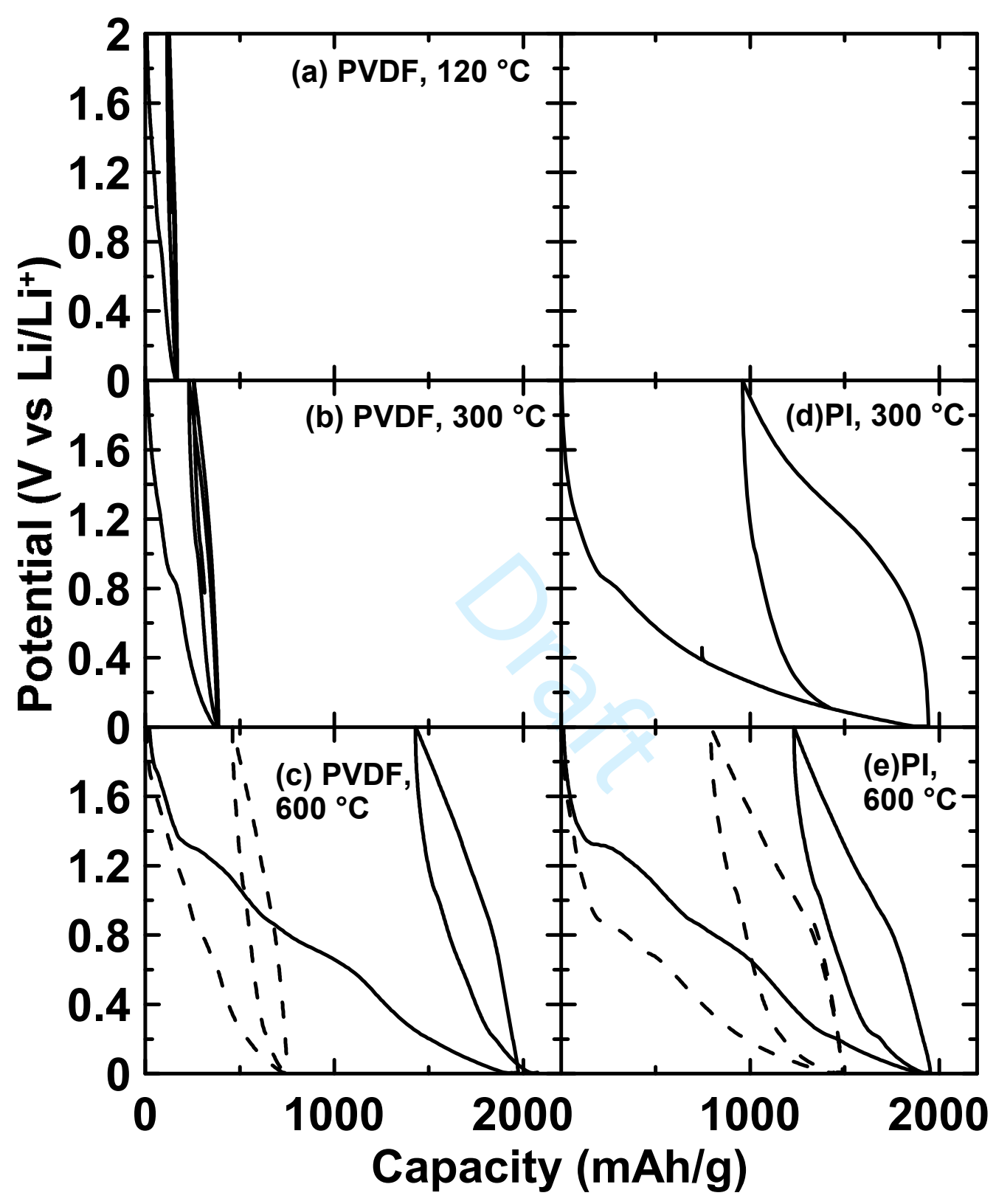


1 Figure 4

2

3
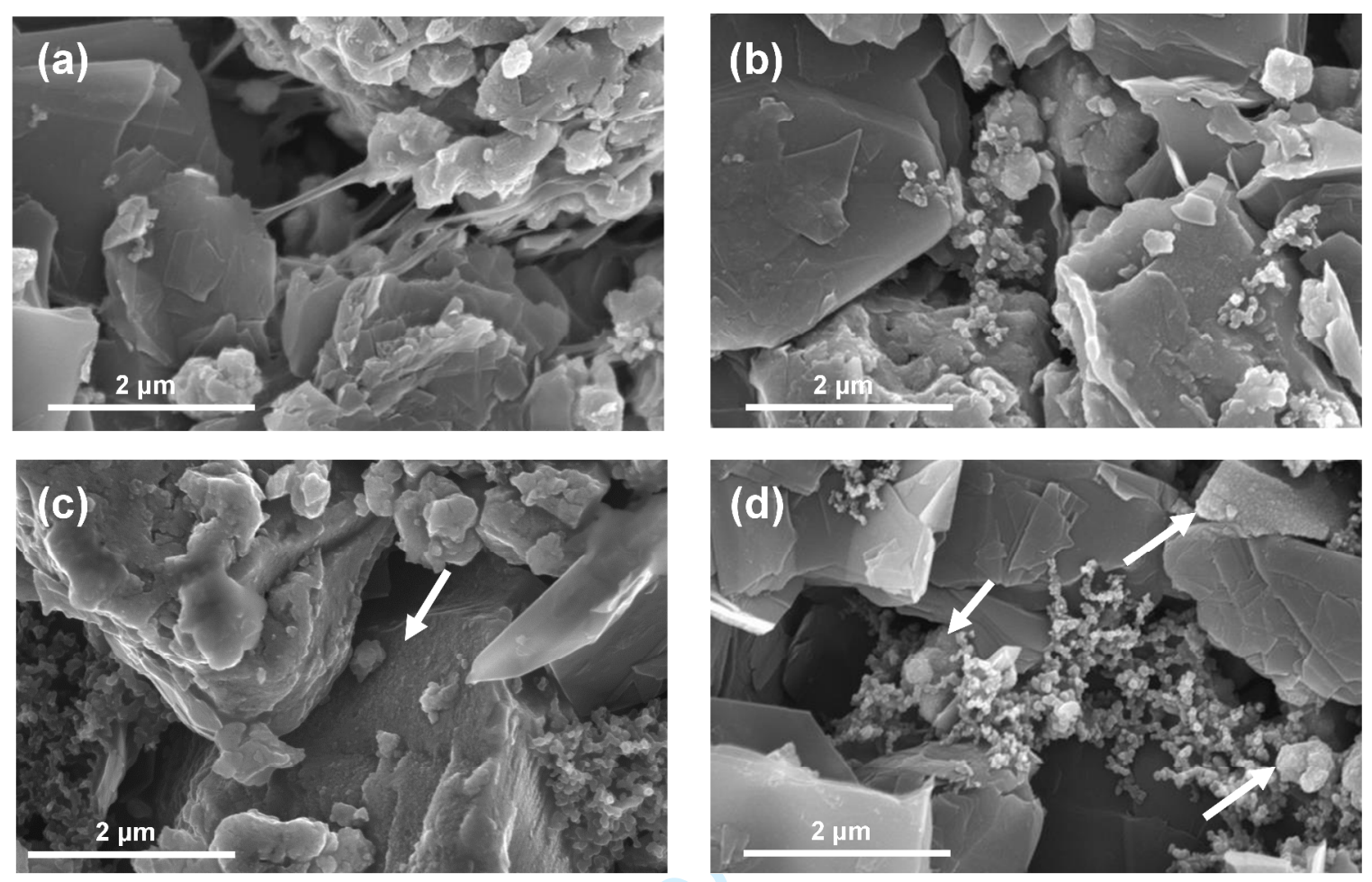
Figure 5
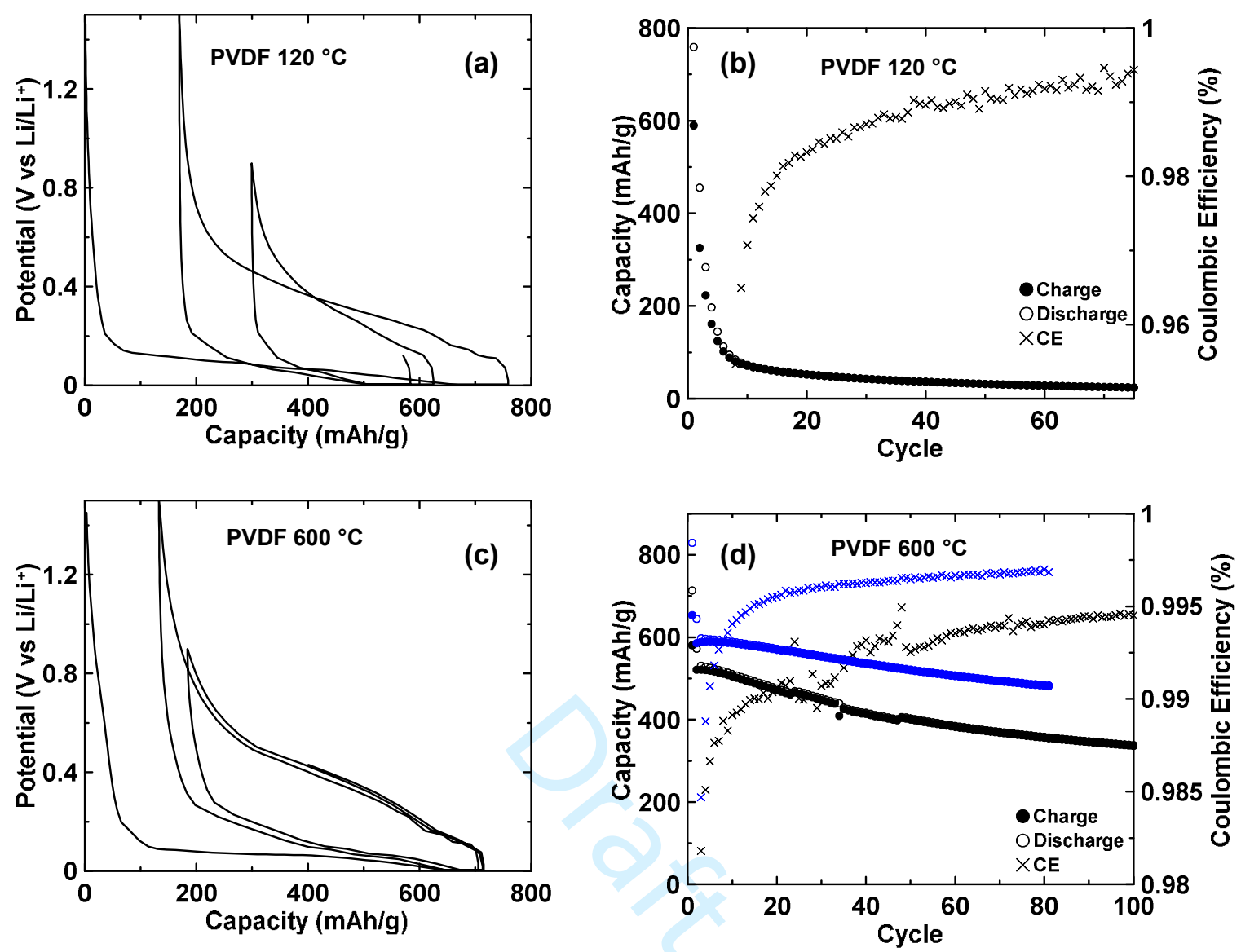
$1 \quad$ Figure 6

2
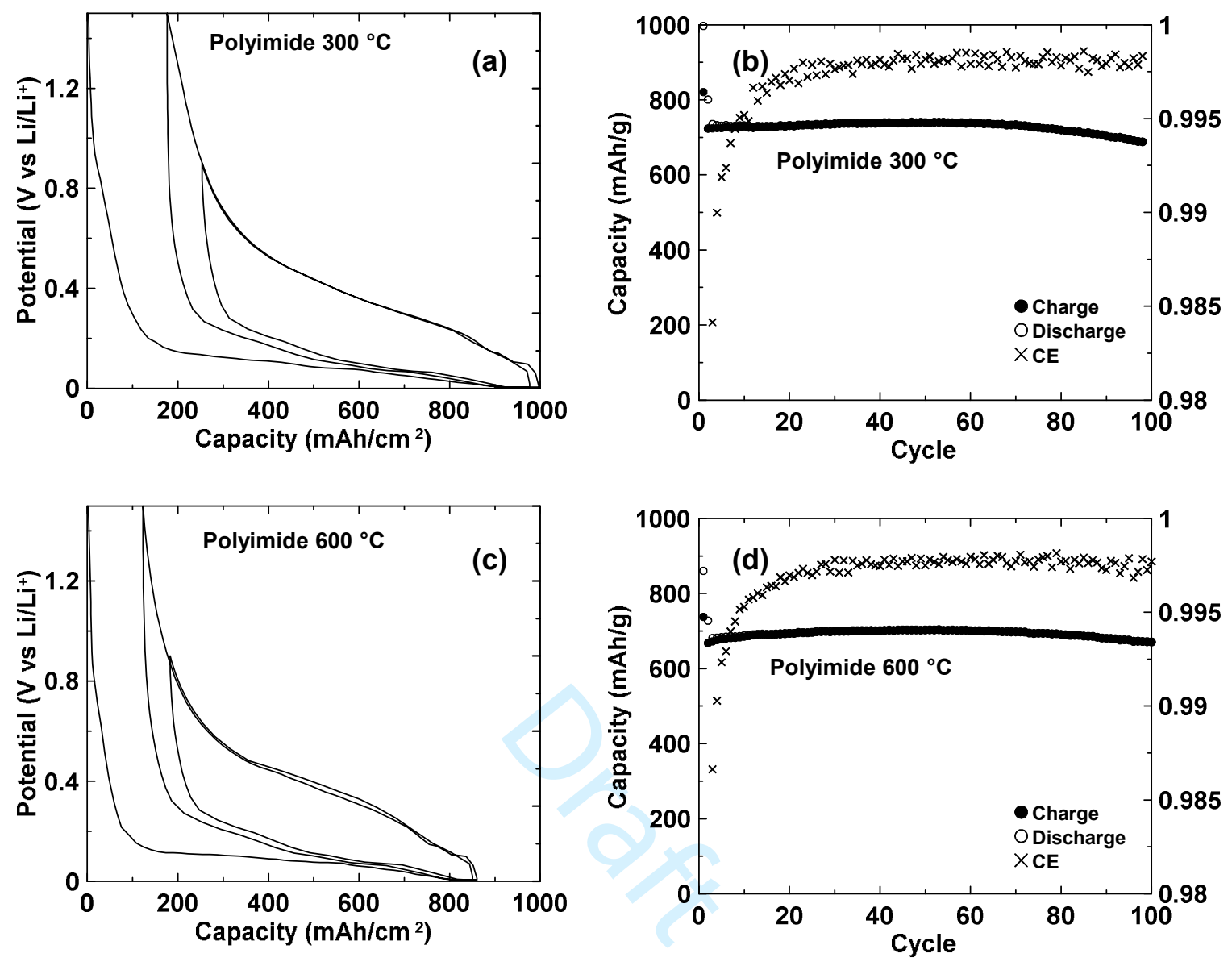

3
4 
$1 \quad$ Figure 7

2

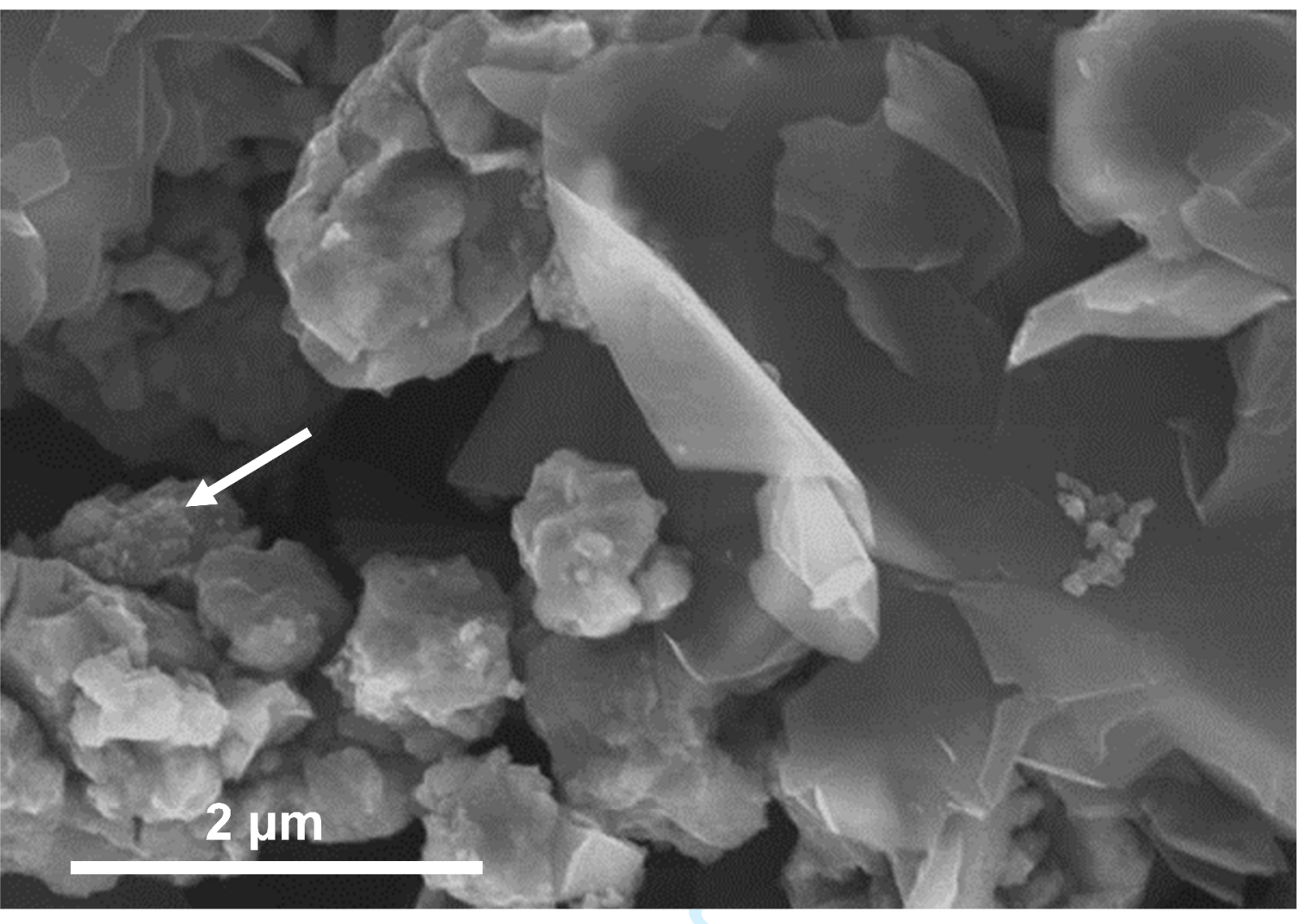

3 